\title{
KALDOR AFTER RICARDO, KEYNES, AND KALECKI: PERSPECTIVES ON THEORY AND POLICIES
}

\author{
Stuart HOLLAND
}

\begin{abstract}
Nicholas Kaldor was a progressive force in economics who made several major contributions, which are well covered by other contributors to this issue in his memory. Yet, like most first generation Keynesians, he stayed within the paradigm of The Concluding Notes to the General Theory, in which Keynes claimed that provided the State intervened to manage the level of demand, the supply side of an economy could be left to the processes of perfect or imperfect competition, whereas Kalecki realised that oligopoly could influence both macroeconomic aggregates and policies. Like Keynes, he also assumed, with Ricardo, that trade was between different firms in different countries rather than recognising that capital already was multinational and that this could qualify both exchange rate changes such as that of the sterling in 1967 and his regional employment premium and selective employment tax.
\end{abstract}

Keywords: Ricardo, Keynes, Kalecki, oligopoly, multinational capital, exchange rates

JEL classification indices: A10, B10, F12, H11, N20, N90

Stuart Holland, Senior Research Fellow at the Institute for Advanced Studies Köszeg, Hungary and Visiting Professor at the Faculty of Economics of the University of Coimbra, Portugal.

E-mail: sholland@fe.uc.pt 


\section{MEETING KALDOR}

I knew Nicky Kaldor well. He was full of humour, humanity, and immensely generous in intellectual terms to alternative points of view. It was not without reason that a Treasury wit, playing on Budapest, from which they came, referred to him as Buda and to his counterpart high-level adviser to the 1960s Labour governments, Thomas Balogh as Pest.

I first met him when he had been invited by Pierre Uri (1911-1992), a socialist and right hand of Jean Monnet, to a working group in Paris in 1966 on the implications for both European Economic Community (EEC) and UK agriculture if there were to be a successful British application to join the European Community. Significantly, Nicky could not find anyone in the Treasury, where he was adviser to the then Chancellor Jim Callaghan, who knew more of the Common Agricultural Policy than that it was a price support system rather than the production grants system of the UK. He therefore asked Thomas Balogh, who was advising Harold Wilson, and to whom I was an assistant, whether I could advise and accompany him on the trip to Paris.

I did, preparing a paper for him, which submitted that the EEC could not manage a British deficiency payments, or production grants system, which imposed limits for agricultural support since, while the share of agriculture in the UK was only some 3\% of GDP, in France, Germany, and Italy it was at or over a fifth. In the UK, the Ministry of Agriculture could evaluate the production potential of individual farms since it was only dealing with few tens of thousands of them. In the EEC, such evaluation would have involved millions of them. In 1966, the price levels for EEC support had not been agreed. They were to be so only in 1968. However, the differences in principle were clear and the outcome of price support without production limits in the EEC predictable - wine lakes and Grain Mountains.

Yet the outflow from agriculture in the Community already was dramatic, and on past and projected trends could reduce the share of the working population in agriculture within some 15 years to levels at which the Community could, in principle, adopt a production grants system, i.e. giving support for a limited output if world prices fell below a given level. This was part of the basis on which, a decade later, I was able to gain the support of De Gaulle, through negotiation with his then Interior Minister Louis Joxe, for a second British application to join the EEC, combined with joint financial support for the sterling and franc zones and a European Technology Community in which the UK, with the EFTA countries which would be likely to follow her lead, plus other EEC member states, could share the costs of France's extensive advanced technology projects which the French Ministry of Finance already had indicated to me could not be supported 
without the risk of "grave social tensions", and which were to transpire in May 1968 (Holland 2015b).

It was generous of Nicky to take me with him to Paris. I suspect he paid the fare himself. On the flight from London, he insisted that I sit next to him and let me lead him through the arguments. Then thanking me warmly and saying that he could support them and would insist that I also spoke at the meeting. Yet when the meeting started and he was invited by Pierre Uri to give his views on the compatibility or otherwise of the two support systems, relapsed into something with which he felt far more at home - Ricardo's principle on diminishing returns from marginal land. After some 45 to 50 minutes of expounding this, he then suggested that I relate it to the issue in hand. Which I did. Then, when the meeting ended, he not only thanked me warmly, but also pushed a wad of French francs into the breast pocket of my jacket insisting nonetheless that I spend them at a particular nightclub whose name, if I remember rightly, was the Crazy Horse, which I did.

However, if this recollection, with others, is altogether warm, a cooler evaluation of Kaldorian economic policies as he advised and gained them in the 1960s nonetheless is merited. In particular, these stayed within the Keynesian paradigm of The Concluding Notes to the General Theory, in which Keynes claimed that provided the State intervened to manage the level of demand, the supply side of an economy could be left to the processes of perfect or imperfect competition. And, while a master of Ricardian economic theory like Keynes and other first generation Keynesians, he assumed, with Ricardo, that trade was between different firms in different countries rather than recognising that capital mobility in the form of foreign direct investment already meant that British firms were four times more multinational than those of leading competitors such as Germany or Japan, and that this profoundly qualified devaluation as a means of gaining export competitiveness.

In the 1960s, Labour governments to which they both were advisers, he and Thomas Balogh were strong advocates of devaluation. Despite being forbidden even to mention it by Harold Wilson, they did so either when together or by phone in Hungarian. Yet without realising, even if this was common at the time, that the multinational companies, which already dominated UK visible exports would not follow through the 1967 devaluation with lower prices in foreign markets since this would be to compete against themselves abroad. His Selective Employment Tax (SET) aiming to discourage services and promote manufacturing had limited effect since big business was not influenced by fiscal policy in its investment decision-making since it could largely self-finance investment from retained earnings. His Regional Employment Premium (REP) assumed different firms in different regions, and that they would thereby gain a regional "devaluation" increasing their competitiveness, which was compromised for the same 
reason. More significantly, he therefore did not deploy his great intellect to follow Kalecki in recognising the degree to which oligopolistic enterprise could compromise a Keynesian micro-macro synthesis.

\section{THE RICARDIAN PALL}

In his Glasgow Lectures of 1763, Adam Smith advised that, if trade were freed from the constraints of taxes, tariffs and "the costs of carriage",

"The cotton and other commodities from China would undersell any made with us, were it not for the long carriage, and other taxes that are laid upon them" (Smith 1763: 141-142).

Smith also had observed in the same lectures that a key restraint on China gaining this advantage was that it was "inward looking". Whereas now, for decades, it has been encouraging inwards investment, and the low cost of what it can produce is out competing much to most of the rest of the world in many manufactures, not least since European, US, Japanese, and Taiwanese companies have been producing in and exporting from China (McKinsey 2010).

By contrast with Smith's recognition of what amounted to absolute advantage in trade, Ricardo (1817) submitted that if an economy were more efficient than others in all production, it would be comparatively more efficient in some products and to its advantage to specialise exports in them. Thus, as well known, he claimed that it would pay English exporters to specialise in cloth and Portuguese exporters to specialise in wine.

Yet this displaced that it is not countries that decide how to specialise - or diversify - in trade, but companies. Moreover, Ricardo's claim was a grand deceit. For he admitted that such trade only would be to the reciprocal advantage of Portugal and England if there were no capital mobility, since otherwise English capitalists would prefer to make both wine and cloth in Portugal, where wages were significantly lower at the time, as they still are. As he put it,

"Under such circumstances capital moves from one country to another [and] the wine and cloth should be made in Portugal" (Ricardo 1817, part VII: 136).

He then simply asserted that capital mobility was unlikely to occur, claiming that,

"Experience, however, shews, that the fancied or real insecurity of capital, when not under the immediate control of its owner, together with the natural disinclination which every man has to quit the country of his birth and connexions, and 
intrust himself, with all his habits fixed, to a strange government and new laws, checks the emigration of capital" (Ricardo ibid: 136-137).

But "experience" showed nothing of the kind. It was investment by the British and Dutch East India companies that had been the foundations of the fortunes that Ricardo and his family made on the Amsterdam and London stock markets after they had left Portugal.

Ricardo also chose to displace that it was English capital that already had invested in and developed the Portuguese wine trade, controlling its whole value chain from vineyards, production, and shipping through to final sale. This was especially in port, which was the wine of choice for the English upper middle class at a time when gin, which could be locally produced, was deemed the downfall of the working class. English brand names still dominate most port on international markets such as Churchill, Croft, Dow, Gilbey, Graham, Offley, Taylor, or Warr.

The trade in port and other Portuguese wines in Ricardo's time therefore was not an example of comparative advantage with no capital mobility, but evidence of foreign direct investment by nascent British multinational capital. Which, a century and a half later, was fully fledged. Thus, by the $1960 \mathrm{~s}$, the value of production outside the UK by British firms was more than double visible exports while, for key competitors such as Germany and Japan, it was less than 40\% (Holland 1975). Which compromised not only the devaluation that Kaldor and Balogh espoused, but also the REP and SET.

\section{QUALIFICATION OF THE 1967 STERLING DEVALUATION}

Two analyses in the 1970s of the effects of the 1967 sterling devaluation, including a study of the top 220 exporters which accounted for two-thirds of UK visible exports, found that none of them had chosen to lower export prices because of the devaluation, and that where some of them had done so, this had been for other reasons such as oligopolistic price strategies either to gain foreign market entry or to deter new entrants (Hague et al.1974; Holmes 1978).

The authors of the reports were perplexed that such firms apparently were not interested in profit maximisation. They neglected that all of the top 220 exporting from the UK already were multinational companies and that to follow through the 1967 sterling devaluation with lower prices in other markets would have been to compete against themselves abroad and reduce global profits.

This is not to claim that exchange rate changes are unimportant. They are vital for countries with little foreign direct investment, and denying devaluation as a means of adjusting trade imbalances has been a critical disadvantage for the economies of peripheral Europe (Varoufakis - Holland 2011). But the effects are 
asymmetric. A revaluation or re-appreciation of a currency will tend to reduce export competitiveness. But a devaluation of it for an economy with a high degree of outward foreign direct investment will not necessarily increase it (Holland 1975, 1987b, 2015a).

Nor is the case to claim that either Kaldor or Balogh were wrong to argue for the devaluation of sterling in the 1960s. Nor were they alone among first generation Keynesians. But not for the reasons that they gave in terms of anticipating an increase in the competitiveness of "British" firms. Harold Wilson also was wrong on this. He had opposed devaluation when sterling was under pressure in mid-1966 not because he lacked any knowledge of Keynesian economics, but because he had given assurances that sterling would not be devalued and put his personal reputation beyond recognition that a devaluation in July that year would be preferable to the deflationary package, which both undermined confidence in the government and destroyed the expansionary expectations of the 1965 National Plan.

\section{COMPROMISE OF THE REGIONAL EMPLOYMENT PREMIUM}

The multinational trend of British capital also qualified REP. Introduced in 1967, this was supposed to amount to a regional devaluation for the UK Development Areas, enabling them to compete more effectively with those, which already were more developed. Moore et al. (1986) calculate that in 1971, 63,000 jobs were being supported by REP and that, of these, about a third (in some 240 firms) were new locations in the Development Areas. But that of policy induced net job gains in development areas, only $16 \%$ were due to REP, with industrial development certificates (IDCs), which had been introduced by the post-war Labour government, being far more significant. IDCs meant that no firms could expand investment for more than 15,000 square feet in the South East. Estimates suggest that they had induced firms to provide 89,000 jobs in the Development areas by 1971 . IDCs were by far the most cost-effective measure (in treasury terms) since they included advance factory construction in the regions and minor incentives, but no ongoing cash subsidy. By contrast, REP was the most expensive of all regional development incentives in terms of cost per job.

Yet, like the $40 \%$ regional investment grants offered by the 1960s Labour governments, they were of little interest to UK multinational firms. In 1973, when I was adviser to a Sub-Committee of the Expenditure Committee of the House of Commons, I persuaded it to take evidence on the effectiveness of regional development incentives from some 70 of the top manufacturing firms in the UK, all of which were multinationals. While some of them had gone to less developed 
regions in the UK, none of them admitted that this had been because of either the Regional Employment Premium of the $40 \%$ investment grants.

When asked with some exasperation why not by the then chair of the Committee, Bill Rodgers, the head of a leading electronics multinational replied that his company, like others, already was investing in Hong Kong, Taiwan, the Philippines, Mexico, and Brazil, where the cost of labour was a tenth or less than that of UK labour, and that labour could constitute $40 \%$ or more of total costs, with which the Regional Employment Premium could not compete (HoC 1973-1974). While, with some relevance now to the prospect that a Brexit may cause devolution in Scotland, John Firn, who later became director of the Scottish Development Corporation in the 1970s, reported to the Committee that of the 105 top companies in Scotland at the time, 100 were multinationals (Firn 1973-1974).

\section{DISPLACEMENT IN THE SELECTIVE EMPLOYMENT TAX}

From the onset of the 1964 Labour government, Kaldor advised that a general sales or Value Added Tax (VAT) should be used to replace flat-rate social security contributions. Officials were, however, generally hostile to VAT, believing that it would entail great administrative difficulty. Jim Callaghan's response in April 1966 was a Selective Employment Tax (SET). This aimed to shift labour from service industries with low productivity into higher productivity sectors such as manufacturing.

The policy was designed to support exports, particularly in the context of devaluation. In addition, it was believed that the service sector, and in particular the retail sector, was using "excessive" labour (1973). A government commissioned evaluation of it by Reddaway was generally favourable, arguing that the reduction in employment in the retail sector had led to an improvement in productivity. Nevertheless, independent research did not support this result rather than that there were no obvious increases in productivity in manufacturing (Broadberry - Leunig 2013). A National Institute of Economic and Social Research analysis (Price 1978) also estimated its effect on exports to be virtually zero. With the benefit of hindsight, it is clear that SET suffered from the same displacement by the first generation of Keynesians of the dual dimensions of oligopoly and the multinational trend of leading British firms or foreign firms located in the UK. SET was eventually abolished in 1971 by the Heath government. 


\section{KEYNES, KALECKI, AND KALDOR}

Oligopoly also means that smaller national exporters will not necessarily follow through devaluation in foreign markets. If they were to do so by charging lower prices in them, they would be competing against bigger multinational business already located there and could invite retaliatory "no entry" or "elimination" pricing by which such firms could lower price to a point at which their micro challengers could not even meet their current variable costs, i.e. pay suppliers or even wages (Sylos-Labini 1968; Holland 1987a).

This was part of a general neglect both by Keynes and among first generation Keynesians of oligopoly and, with it, the stress laid on this by Kalecki (1943, 1954), who was influenced by Marx, whereas Keynes was not. Kalecki recognised that the oligopoly power of a few firms on the supply side of the economy could influence macroeconomic outcomes, which Keynes never did. He also realised that Keynesian full employment could increase the power of organised labour, and with it possible inflationary pressures, which Keynes had recognised. But he anticipated also that full employment would change the relations of power between capital, labour and the State. As he put it,

"The assumption that a government will maintain full employment in a capitalist economy if it only knows how to do it is fallacious. In this connection the misgivings of big business about maintenance of full employment are of paramount importance" (Kalecki 1943: 144).

Kalecki added that opposition to this from big business and profit-seeking rentiers - disagreeing with Keynes' presumption that their disappearance with full employment would be inevitable - could prevent governments in the longer term from sustaining full employment. Adding that even higher profits with full employment would neither necessarily change their view, nor their opposition to policies for redistribution, since this would imply a change in the balance of power from themselves towards governments and the institutions of civil society. Moreover, he also presciently submitted that the vested interests of big business

“...would find more than one economist to declare that the [full employment] situation is manifestly unsound. The pressure of all these forces, and in particular of big business would most probably induce government to the orthodox policy of cutting down the budget deficit"'(Kalecki ibid). 


\section{SUMMARY}

None of the above is to neglect where Kaldor and the first generation Keynesians were right. They stressed the vital importance of effective demand to offset recession or depression and to raise both economies and societies to higher levels of employment, income, and welfare. Also, the need for effective taxation as well as capital controls.

Kaldor also was more right than Keynes in being concerned with disproportion between sectors and more concerned than him also with uneven development. His attacks on equilibrium assumptions in macroeconomic theory (Kaldor $1934,1972,1979)$ were notable. For change is not realistically captured by comparisons of static equilibria - transition from one equilibrium state to another - as by Samuelson (1947) in his influential Foundations of Economics, nor by John Hicks (1965) in his Capital and Growth, both of which assumed "neutral" technical progress which denies the asymmetric outcomes from innovations that Schumpeter (1934) had seen as raising economies and societies to higher levels of income and welfare.

Yet he remained dependent, as had Keynes, on the Ricardian assumption that trade was between different firms in different countries, which qualified his case both for devaluation of a national currency such as that of the UK, and his case for REP as a means of increasing the competitiveness of UK regions. In staying with Keynes' presumption that the supply side of the economy can be left to perfect and imperfect competition, he did not follow through Kalecki or Sylos-Labini in recognising the degree to which oligopoly can dominate macroeconomic outcomes and qualify the scope for market entry of smaller micro firms. Nor that development could need not only the State managing the level of demand or creating the conditions for private sector firm creation, but also State entrepreneurship, as was to be a key element of the policies of the Labour Party in the 1970s with the creation of a British National Oil Corporation, a National Enterprise Board, and Scottish, Welsh and Northern Ireland Development Agencies.

\section{REFERENCES}

Broadberry, S. - Leunig, T. (2013): The Impact of Government Policies on UK Manufacturing since 1945. Government Office for Science, October.

Firn, J. R. (1973): Memorandum to the Expenditure Committee Trade and Industry Sub-Committee. Evidence on Regional Development Incentives Session, 1973-4: 694-712.

Hague, D. E. - Oakeshott, W. E. - Strain, A. A. (1974): Devaluation and Pricing Decisions. London: Allen \& Unwin.

Hicks, J. (1966): Capital and Growth. Oxford: Oxford University Press. 
HoC (1973-4): House of Commons Expenditure Committee, Trade and Industry Sub-Committee. Regional Development Incentives Session, 1973-4.

Holland, S. (1975): The Socialist Challenge. London: Quartet Books.

Holland, S. (1987a): The Market Economy: from Micro to Mesoeconomics. London: Weidenfeld and Nicolson.

Holland, S. (1987b): The Global Economy: from Meso to Macroeconomics. London: Weidenfeld and Nicolson.

Holland, S. (2015a): After Ricardo - after Marx - after Keynes: Comparative Advantage, Mutual Advantage and Implications for Global Governance. Review of Keynesian Economics, 3(1): January.

Holland, S. (2015b): Europe in Question and What to Do about It. Nottingham: Spokesman Press.

Holmes, P. (1978): Industrial Pricing Behaviour and Devaluation. Basingstoke: Macmillan.

Kaldor, N. (1934): A Classificatory Note on the Determinateness of Equilibrium. Review of Economic Studies, February, 122-136.

Kaldor, N. (1972): The Irrelevance of Equilibrium Economics. Economic Journal, 82: 12371255.

Kaldor, N. (1979): Equilibrium Theory and Growth Theory. In: Boskin, M. J. (ed.) (1979): Economics and Human Welfare: Essays in Honour of Tibor Scitovsky. New York: Academic Press, pp. 273-291.

Kalecki, M. (1943): Political Aspects of Full Employment. Political Quarterly 14(4). 322-330.

Kalecki, M. (1954): Theory of Economic Dynamics: An Essay on Cyclical and Long-Run Changes in Capitalist Economy. New York: Reinhart and London: Allen \& Unwin.

Keynes, J. M. (1936): The General Theory of Money, Interest and Employment. London: Macmillan.

McKinsey \& Company (2010): Growth and Competitiveness in the United States: The Role of Its Multinational Companies. June.

Moore, B. - Rhodes, J. - Tyler, P. (1986): The Effects of Government Regional Economic Policy. London: HMSO.

National Institute of Economic and Social Research (NIESR) (1971): The Productivity Effects of the Selective Employment Tax. National Institute Economic Review, 56(1): 36-40.

Price, R. W. R. (1978): Budgetary Policy. In: Blackaby, F. T. (ed.): British Economic Policy, 196074. Cambridge, MA: Cambridge University Press, pp. 144-149.

Reddaway, W. (1973): Effects of the Selective Employment Tax. Final Report. Cambridge, MA: Cambridge University Press.

Ricardo, D. (1817): On the Principles of Political Economy and Taxation. London: John Murray. (Revised and republished by Sraffa, P. - Dobb, M. H., Cambridge, MA: Cambridge University Press, 1951.)

Samuelson, P. A. (1947): Foundations of Economic Analysis. (Republished an enlarged edition, Harvard Economic Studies 80, Cambridge, MA: Harvard University Press, 1983).

Schumpeter, J. A. (1934): The Theory of Economic Development: An Inquiry into Profits, Capital, Credit, Interest, and the Business Cycle. Harvard Economic Studies 46, Cambridge, MA: Harvard University Press.

Smith, A. (1763): The Glasgow Lectures. In: Napoleoni, C. (1975): Smith, Ricardo, Marx. Oxford: Blackwell, pp. 136-152.

Sylos-Labini, P. (1956): Oligopolio e progresso tecnico (Oligopoly and Technical Progress). Milano: Giuffré. (Translated into English and published by Cambridge, MA: Harvard University Press, 1962.)

Varoufakis, Y. - Holland, S. (2011): A Modest Proposal for Overcoming the Eurozone Crisis. Levy Economics Institute of Bard College, Policy Note, 2011/3. 